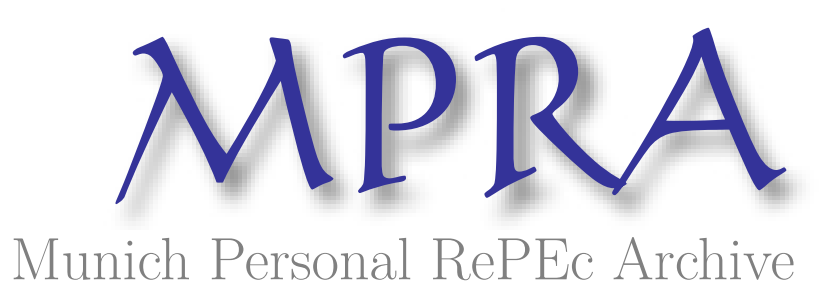

\title{
Does Higher Education Increase Hedonic and Eudaimonic Happiness?
}

Nikolaev, Boris

Baylor University

2016

Online at https://mpra.ub.uni-muenchen.de/78438/

MPRA Paper No. 78438, posted 17 Apr 2017 10:53 UTC 


\title{
Does Higher Education Increase Hedonic and Eudaimonic Happiness?
}

\author{
Boris Nikolaev * \\ Oxford College of Emory University
}

May 29, 2016

\begin{abstract}
An increasing number of studies suggest that the relationship between higher education and subjective well-being (SWB) is either insignificant or negative. Most of these studies, however, use life satisfaction as a proxy for SWB. In this study, using longitudinal data from the Household Income and Labor Dynamics in Australia (HILDA) survey, I examine the link between higher education and three different measures of subjective well-being: life satisfaction and its different sub-domains (evaluative), positive and negative affect (hedonic), and engagement and purpose (eudaimonic). Three substantial results emerge: (1) people with higher education are more likely to report higher levels of eudaimonic and hedonic SWB, i.e., they view their lives as more meaningful and experience more positive emotions and less negative ones; (2) people with higher education are satisfied with most life domains (financial, employment opportunities, neighborhood, local community, children at home) but they report lower satisfaction with the amount of free time they have; (3) the positive effect of higher education is increasing, but at a decreasing rate; the SWB gains from obtaining a graduate degree are much lower (on the margin) compared to getting a college degree.
\end{abstract}

Keywords: Subjective Well-being, Returns to Education, Panel Estimation

JEL Classification Numbers: I0, J24, I21, I31.

\footnotetext{
*Address: 110 Few Circle, Oxford, GA 30054, Phone: 813.401.9756, E-mail: boris.nikolaev@emory.edu, Website: www.borisnikolaev.com
} 


\section{Introduction}

Education is widely acknowledged as one of the most important investments in human capital that helps individuals develop a multitude of skills that provide many tangible and intangible benefits. Hundreds of academic studies in different times and places show that better educated people live longer and healthier lives, are more likely to marry successfully, experience higher quality of interpersonal relationships, and have more opportunities on the labor market (Oreopoulos and Salvanes, 2011). Yet, an increasing number of studies in the emerging field of happiness economics have documented an insignificant relationship between higher education and subjective well-being with some studies suggesting that the relationship is strictly negative (Clark and Oswald, 1995; Shields et al., 2009; Powdthavee, 2010; Nikolaev, 2015). In a recent review of the happiness literature, Veenhoven (2010) concludes that school education is the only capability that does not seem to make people happier.

There are several possible explanations for this puzzling observation. The most common one is that higher education can make people more ambitious which might reduce life satisfaction since higher aspirations are more difficult to fulfill (Clark and Oswald, 1995). College graduates, for instance, are known to experience higher levels of stress related to unemployment than their less educated counterparts. It is also possible that less happy people are more likley to pursue higher education, which drives the results in many correlational studies (Veenhoven, 2010). Another possible story is that most studies estimate reduced form happiness regressions that often control for variables such as income, health, and marital status and thus close these channels through which education may contribute positively to higher levels of SWB (Powdthavee et al., 2015). A more recent explanation suggests that people are willing to trade off some of their overall happiness for an upward trajectory in life (Nikolaev and Rusakov, 2015). Finally, it is also likely that people pursue higher education for the sake of social status. Nikolaev (2016), for example, finds that people with relatively higher education within their reference group report much higher levels of life satisfaction.

Majority of these previous studies, however, use life satisfaction as a proxy for SWB. 
Yet, it is by now widely recognized that SWB has multiple dimensions which are only weakly correlated with each other (Kahneman and Deaton, 2010; Stiglitz et al., 2009). More generally, there are three different types of SWB measures: (1) evaluative, (2) hedonic, and (3) eudaimonic. The first one, which is most commonly used in happiness studies and is usually proxied with survey questions on life satisfaction, reflects a cognitive evaluation of one's life. Here, individuals are asked to make statements about how their life is going in general (or as a whole). A second type of measure has to do with the balance between positive and negative emotions in people's daily lives. This type of SWB is often called hedonic or affective well-being (Diener et al., 2002). Lastly, there are non-hedonic/evaluative measures, which usually capture meaning, purpose, or accomplishment, which are often called eudaimonic (Clark, 2016). These measures reflect people's innate psychological needs for belonging, autonomy, self-esteem, or mastery and are sometimes related to Maslow's hierarchy of needs (Maslow, 1943) or the theory of self-determination (Deci and Ryan, 2002). Seligman (2012), for example, argues that well-being, or what he calls authentic happiness, is a function of these three different types of SWB. He puts an emphasis on the eudaimonic happiness, which according to him is the most lasting one. It is also important to mention that while most economists recognize that SWB is an important argument in the utility function, they also believe that there are many others. In that sense, people constantly make trade-offs between their SWB, and its different dimensions (positive emotion vs meaning) and other aspects of their lives such as achievement or their personal relationships.

In this paper, I contribute to this line of research in three ways. First, I provide a number of empirical tests using longitudinal data from the HILDA dataset on all three types of SWB: (1) evaluative, (2) hedonic, and (3) eudaimonic. Second, following the approach proposed by Van Praag et al. (2003), I furthermore examine the relationship between higher education and ten different life domain satisfactions (DS). Finally, I investigate the effect for four different levels of educational attainment - less than high school, high school, college, and graduate school. Since an increasing number of people pursue advanced degrees today (beyond a college diploma), it is important to understand the incremental SWB benefits associated with each level of educational attainment and not just the return from a college degree as in most previous studies. The richness of the HILDA dataset furthermore allows 
me to control for a large set of confounding variables including personality traits and to use variation within a person's lifetime as well as across individuals.

Three substantial results emerge: (1) people with higher education are more likely to report higher levels of eudaimonic and hedonic SWB, i.e., they view their lives as more meaningful and experience more positive emotions and less negative ones; (2) people with higher education are satisfied with most life domains (financial, employment opportunities, neighborhood, local community, children at home) but they consistently report lower satisfaction with the amount of free time they have; (3) the positive effect of higher education is increasing, but at a decreasing rate; the SWB gains from obtaining a graduate degree are much lower (on the margin) compared to getting a college degree.

These results shed light on some of the previous contradictory empirical findings in the literature and suggest that higher education has large SWB returns, especially when it comes to eudaimonic and hedonic happiness. The findings also suggest one possible reason why more educated people report lower levels of life satisfaction-while people with higher degrees have more fulfilling and meaningful jobs, they also have less time to enjoy other aspects of their lives. Finally, the results in this study point to important trade-offs between these three different types of SWB that people could be making when choosing to go to college.

\section{Theoretical Considerations}

The role of education in promoting individual well-being has been widely explored in the academic literature. Most of the earlier studies examine the indirect effect of education on happiness through the income channel. Starting with Becker (2009), the emphasis of economic analysis has been on the financial return from schooling. ${ }^{1}$ The basic assumption is that higher income leads to greater consumption which increases individual utility. A large number of studies using different estimation techniques and considering factors such as intelligence, ability, and family background find that, on average, an additional year of schooling increases personal income from 7 to 12 percent (Card, 1999).

\footnotetext{
${ }^{1}$ Almost all of these studies are indebted in the human capital earnings model first developed by Mincer (1974). For a review of this literature, see Card (1999).
} 
More recently, economists have started investigating the effect of education on a variety of other, non-pecuniary outcomes, such as enjoyment from work, health, marriage, and parenting decisions that are also linked to subjective well-being. In a recent study, Oreopoulos and Salvanes (2011) conclude that these non-pecuniary returns from education are as large as the pecuniary ones. In this section, I review the literature on the non-pecuniary benefits which are realized directly by the student. ${ }^{2}$

\subsection{Non-monetary Returns in the Labor Force}

An obvious benefit of education is that it facilitates students in the process of self-discovery and helps them find careers that are a better match for their talents, interests, and aspirations. Another form of non-pecuniary benefit in the labor force is that education provides individuals with the option to obtain even higher education. Higher educational credentials usually come with more employment choices. A third benefit is the increased ability to adjust to changing job opportunities (for example, due to rapid technological change). ${ }^{3}$ In this case, adaptability is seen as an output from obtaining a higher degree.

Having a good education, then, increases the likelihood of finding a job and earning higher income and decreases the reliance on social assistance. The long-term and negative effect of unemployment on subjective well-being is well-established in the economic literature (e.g., see Di Tella and MacCulloch (2006)). But more education can also increase the likelihood of finding not just a job, but a job that is more interesting, meaningful, safer, more prestigious, and ultimately more enjoyable. Several recent studies find that people with more education are also more likely to find a more satisfying job, and have greater autonomy and independence at work (Albert and Davia, 2005). Similarly, Oreopoulos and Salvanes (2011) show that workers with similar backgrounds, but more schooling, have jobs that offer a greater sense of accomplishment and are more prestigious.

\footnotetext{
${ }^{2}$ In this study, I discuss the private return from education. There is a large literature that is dedicated to the external benefits of education to society. Higher education, for example, is positively correlated with economic growth and development.

${ }^{3}$ See Weisbrod (1962) for a more detailed discussion of these non-monetary benefits
} 


\subsection{Non-monetary Returns Outside of the Labor Force}

Even though economist usually focus on the returns of higher education in the labour force, a great deal of the value of education is realized in terms of better choices and opportunities outside of the labor market. Grossman (2006) provides a more general (theoretical) framework that outlines how cognitive development generates returns to students in other domains of life through productive and allocative efficiency. The productive efficiency model suggests that education teaches students time and resource management skills that allow them to achieve better outcomes with less resources - more educated people are able to do more with less. On the other hand, the allocative efficiency model suggests that education helps people make better choices which allows them to achieve superior outcomes with the same level of resources. In this respect, a key non-monetary benefit from additional education is improvement in physical and mental health.

The most obvious benefit from better health is reduced health care costs and longer life which may translate into higher productivity and lifetime earnings. But good health can also increase access to education, jobs, and improve social relations which may also enhance economic opportunities. The positive association between higher education and health is well-established in the literature [e.g., see Cutler and Lleras-Muney (2006); Mirowsky and Ross (2003)]. People with higher education are also more likely to have stronger social networks and to experience a greater sense of control over their life which is associated with better health and happiness (Verme, 2009). More importantly, the better educated are less likely to engage in risky personal habits such as smoking and drinking and are more likely to exercise and get a regular health check-up (Ross and Wu, 1995).

Another non-pecuniary benefit from higher education is that well-educated people, perhaps due to their higher earning potential and higher socio-economic ranking, are more attractive on the competitive marriage market (Becker, 1973; Chiappori et al., 2009). Married people often report significant happiness premium compared to singles (Frey and Stutzer, 2002). Qari (2010), for example, argues that individuals do not fully adapt to the positive spike in happiness from marriage. He estimates the monetary equivalent of these long-term non-pecuniary benefits to be 85,000 Euros per year for men. 
There is also abundant evidence that women with more education have fewer children (Jones et al., 2008). Having fewer children is associated with higher life satisfaction. This negative correlation is often explained by differences in family structure (White et al., 1986). For example, having more children is often correlated to more financial dissatisfaction and more traditionalism in the division of labor. More importantly, educated people tend to be better parents (Leigh, 1998) and parental education is one of the strongest determinants of child development. Recent research, for example, suggests that parental education is correlated with a myriad of positive outcomes - from children's cognitive development in early life to their educational attainment and job prospects later in life (Cunha and Heckman, 2009). One explanation of these findings is that more educated people differ in their parenting styles. For example, better educated parents not only spend more time with their children, but they are also less likely to discipline them and more likely to encourage them to pursue new knowledge and to think independently.

Education is also often described as one of the most robust predictors of social capital and civic engagement (Helliwell and Putnam, 2007). Social capital reflects the idea that social connections - friendships, volunteering, and other relationships - generate value beyond the intrinsic pleasure that people derive from interacting with others.Recent studies also show that spending time with family, friends, and colleagues is associated with higher average levels of positive feelings (Kahneman and Krueger, 2006). But even beyond the intrinsic pleasure that people derive from spending time with others, social connections have a positive external effect on individuals and society. Social networks, for example, provide both material and emotional support in good and bad times. Helliwell et al. (2004) find that social capital (measured by the strength of family, neighborhood, religious, and community ties) is independently and robustly positively correlated with life satisfaction, both directly and through their impact on health.

\subsection{Education and Subjective Well-being}

Based on the literature review above, it is easy to see why some of the recent empirical findings that higher education is not significantly or even negatively correlated with SWB are so puzzling (Clark and Oswald, 1995; Shields et al., 2009; Powdthavee, 2010; Nikolaev, 
2015). Education, after all, can lead to a more successful, meaningful, and happy life through variety of economic and non-economic channels.

Of course higher education may come with some negative non-pecuniary returns. For example, better paid jobs also come with more responsibilities and expectations for improved performance which may lead to longer work hours and more stress at work. Employees that work longer hours may find it challenging to balance their work and daily living. Using data from the General Social Survey, Oreopoulos and Salvanes (2011) point out the tendency for college graduates to report wanting to spend more time with friends and family. Yet, this could be because more educated people value family, friendships, and hobbies more than those who are less educated.

Another negative effect from higher education is the price of unemployment. People with higher degrees have better jobs and earn higher incomes and losing a job has a higher economic cost to them. Clark and Oswald (1994) find that better educated people tend to cope with unemployment less successfully than do those who have lower degrees. In a separate study, Clark and Oswald (1995) show that more educated people report lower levels of life satisfaction. One possible explanation of their findings is that education raises job expectations, which are more difficult to fulfill. Another explanation is that inequality of income increases with social class, and relative income tends to play an important role in determining individual happiness. Several other studies also find a negative association between education and life satisfaction or the absence of a significant relationship between the two (Clark and Oswald, 1995; Shields et al., 2009; Powdthavee, 2010; Klein and Maher, 1966; Warr, 1992; Blanchflower et al., 1992; Nikolaev, 2015, 2016). In a review of this literature from the World Database of Happiness, Veenhoven (2010) concludes that education does not seem to increase the happiness of pupils.

Other studies, however, report a positive and significant relationship even after accounting for some of the indirect channels through which better education may positively affect well-being such as income, marriage, and health. For example, (Cuñado and de Gracia, 2012) study the impact of education on happiness in Spain using individual level data from the European Social Survey and discover that education has a positive (and direct) effect on happiness. The authors attribute this result to greater self-confidence and self-estimation 
which, as they argue, is a result from acquiring knowledge. Oreopoulos and Salvanes (2011) find that more schooling leads individuals to make better decisions about health, marriage, and parenting, and, ultimately, to a happier life. The authors argue that an important way in which school makes people happy is to make individuals more patient, goal-oriented, and less likely to engage in more risky behaviors. And, Powdthavee et al. (2015) find that once you account for the positive effect of higher education on income, health and marriage outcomes, the overall (both direct and indirect) effect of education on happiness is actually positive and substantial.

To the best of my knowledge, majority of these previous studies examine the relationship between education and evaluative happiness, which is most often proxied by life satisfaction. In this study, I complement prior work by examining the link between education and three different types of SWB, including measures of eudaimonic and hedonic SWB. I furthermore, examine individuals satisfaction from ten different life domains-from satisfaction with job opportunities to satisfaction with the amount of free time. Thus, the results in this study provide additional empirical evidence that help better understand the underlying relationship between higher education and SWB.

\section{Data}

Data for the analysis were collected from the Household Income and Labour Dynamics in Australia (HILDA) survey, waves 1-13. The dataset is a large nationally representative panel that collects annually a wide range of information on respondent's socio-demographic characteristics, subjective well-being, labor market participation, and family circumstances. The final sample consists of 20,143 individuals between 22 and 65 years of age and 126,265 individual-year observations for the period 2001-2013. I choose my sample to include people 22 years or older for two reasons. First, majority of people in the sample have completed the highest level of educational attainment by the age of 22 (college degree). This mitigates problems associated with endogeneity since SWB today is less likely to affect the level of education people obtain in the past. Second, this allows me to exclude people who may be currently pursuing a degree and have not yet arrived at their highest level of educational 
attainment and as a consequence may not have realized many of the benefits that a higher degree offers. Nikolaev and Rusakov (2015), for example, shows that the SWB returns from college education increase with age.

Table 1 provides a complete list and summary statistics for all variables used in this study. Due to attrition, which arises when a non-random sample of individuals chooses not to respond, the number of individuals varies from year to year. However, the proportion of respondents from one wave who successfully re-interview in the next wave is reasonably high, from a low of 87 percent in wave 2 to a high of 97 percent in wave 9 (Watson and Wooden, 2012). Finally, many of the previous studies that document a negative relationship between education and happiness use data from the HILDA dataset, which makes it ideal for testing the hypothesis in this paper (Nikolaev, 2015; Powdthavee, 2010).

[Table 1 around here]

\subsection{Life Satisfaction}

The dependent variable, life satisfaction, is collected with the following question: "All things considered, how satisfied are you with your life?" The scale of possible answers is presented using a visual aid in which the extreme points of the scale were labeled 0 'totally dissatisfied' and 10 'totally satisfied'. In that sense, the question reflects an cognitive assessment involving evaluative judgment of one's life as a whole (on the meta level) and requires an effort to remember and evaluate past experiences. Data on domain satisfactions are collected in a similar fashion. In this study, I utilize responses to ten separate life domains that include satisfaction with: (1) employment opportunities, (2) financial satisfaction, (3) amount of free time, (4) the home in which you live, (5) feeling part of your local community, (6) the neighborhood you live, (7) how safe you feel, (8) relationship with children, (9) relationship with partner, and (10) children in household get along with each other. These questions are measures on the same $0-10$ scale as before. 


\subsection{Eudaimonic SWB}

The HILDA dataset contains a unique module that asks respondents a series of questions that evaluate their psychological well-being (distress). A number of these questions are related to concepts of meaning, self-worth, and engagement in daily activities. These measures, although not perfect, provide a good first approximation for eudaimonic SWB. To create a measure of eudaimonic well-being, I use the average of the responses to four different questions that ask respondents to answer how often in the past four weeks they have felt (1) worthless, (2) hopeless, (3) tired for no good reason, and (4) that everything in life was an effort. The first two questions are related to the concept of self-worth and meaning while the latter two to the concept of positive engagement and flow. More specifically, data were collected with: "The following questions are about your feelings in the past 4 weeks. In the last four weeks, about how often did you feel...worthless?" with possible answers recoded as 1 'all of the time', 2 'most of the time', 3 'some of the time', 4 'a little of the time', and 5 'none of the time'. The index that I create, then, is increasing in eudaimonic SWB. The data are available only for waves $7,9,11$, and 13 of the survey, which limits the sample to 53,182 observations.

\subsection{Hedonic SWB}

Similarly, the set of questions that assess psychological distress also asks respondents to evaluate their emotional (hedonic) well-being in the past four weeks. I use the average of five such questions to calculate a measure of hedonic well-being. These questions use the format described above and include: (1) feeling sad, (2) feeling restless or fidgety, (3) feeling nervous, (4) cannot sit still, and (5) cannot calm down. All of these measures are also measured on a scale from 1 'all of the time" to 5 'none of the time' with higher values reflecting higher emotional well-being (less psychological distress).

Cumulatively, the questions on eudaimonic and hedonic well-being described above are part the Kessler Psychological Distress Scale (K10), which is measured on a scale of 10 to 50 and was first developed for screening populations for clinical depression and anxiety (Kessler and Mroczek, 1995). I also include a measure with the overall K10 score of respondents. 


\subsection{Positive and Negative Affect}

As an alternative measure of hedonic well-being, I use responses from a separate module on mental health that include questions about positive and negative feelings that people experience in their daily lives. Specifically, responses were collected using the following format: "These questions are about how you feel and how things have been with you during the past 4 weeks. For each question, please give the one answer that comes closest to the way you have been feeling. How much of the time during the past 4 weeks...Have you been a happy person?" The recoded scale of answers ranged from 1 'none of the time' to 6 'all of the time'. The index of positive affect, then, is created as an average of the following: (1) been a happy person and (2) felt calm and peaceful. Negative affect, on the other hand, reflects answers to questions about: (1) been a nervous person, (2) nothing could cheer you up, (3) felt down, (4) felt worn out, and (5) felt tired. Overall, this second set of measures, positive and negative affect, are closely related to the hedonic measures above and provide an important robustness test.

\subsection{Education}

The measure of education is continuos and reflects years of formal education and is imputed from data that asks respondents to answer what is the highest level of education they have achieved. A respondent who has completed secondary school, for example, is assumed to have completed 12 years of education while somebody with a college degree is assumed to have completed 16 years of education. While we are not measuring the actual number of years spent obtaining a degree, which can vary with the number of degrees or time spent studying that did not lead to a degree, this approach is common in the economics of education literature (Card, 1999). As an alternative measure, I use the highest level of

educational attainment, which is recoded as 1 'less than high school', 2 'high school' 3 'some college' 4 'college' and 5 'graduate degree'. 


\subsection{Other Controls}

There are a number of common socio-demographic variables that are used as controls in this study. The list of these variables includes: age, marital status, sex, employment situation, log of labor income, self-rated health, exercise habits, personality traits, and region and year (wave) dummies. All of these variables also came from the HILDA dataset and are described in Table 1.

\section{Empirical Results}

In this section, I first describe the estimation model and then present the main results.

\subsection{Model}

Even though the dependent variables are measured on a scale (e.g., life satisfaction is measured from 0 to 10) and require an ordered logit estimation, I use a random-effects (RE) linear estimator with robust standard errors clustered at the individual level. I do this for two reasons. First, Kahneman and Krueger (2006) provide extensive evidence for interpreting survey data on SWB as cardinal and comparable, which is common in sociology and psychology. Second, Ferrer-i Carbonell and Frijters (2004) show that the results from OLS and ordered logit regressions hardly ever differ in the context of SWB research. Of course, an additional benefit of using linear estimates is the practical advantage of easyto-interpret marginal effects. Thus, I estimate the following reduced form model which is common in the happiness literature:

$$
S W B_{i t}=\alpha \log y_{i t}+\beta E d u c a t i o n_{i t}+\gamma^{\prime} \mathbf{X}+\epsilon_{i t}
$$

where $\mathrm{i}=$ individual, $\mathrm{t}=$ year, and $\mathbf{X}=\mathrm{k}$ explanatory variables (including age, age squared, marital status, employment situation, and a logarithmic transformation of personal income, $\log y$ ), Education $=$ years of education (or five levels of educational attainment), and $\epsilon_{i t}$ is 
an idiosyncratic error:

$$
\epsilon_{i t}=\nu_{i}+\mu_{i t}
$$

where $\nu_{i}$ represents individual specific fixed-effects and $\mu_{i}$ is the usual error term. As common, the error terms are assumed to be random and not correlated with the explanatory variables. However, this assumption is likely to be violated, especially when it comes to the fixed-effects term. For example, each individual may be using his or her own scale when answering the happiness question, which is unobserved to the researcher. This issue is still one of the major methodological stumbling blocks in happiness research. Moreover, unobserved individual specific characteristics such as ability, motivation, or family background are most likely correlated with both SWB and other explanatory variables such as income and education.

In the context of longitudinal data, there are two methods to deal with the correlation of the individual observations over time: (1) random-effects (RE) and (2) fixed-effects (FE) model. I choose the first approach for several reasons. First, the random-effects estimator is largely preferred in most branches of applied statistics (Cameron and Trivedi, 2009). More importantly, however, the educational variable does not vary substantially over the course of most adults lifetime, which makes relying only on within individual variation problematic.

In addition, Van Praag and Ferrer-i Carbonell (2008) suggest that the use of RE model is more appropriate in the context of happiness reserach. This is because $\nu_{i}$ is an unknown parameter in the FE model that needs to be estimated. This means that for 20,000 individuals (as in the case of this study), 20,000 extra parameters (1 extra parameter per person) need to be estimated. This is hardly what we call a parsimonious model. Even more importantly, using a RE model allows for the possibility of estimating both level and shock effects. However, by using $\mathrm{N}$ individual fixed effects, there is no place for a level effects to be estimated and only shock effects can be estimated that require significant variation over time. This, again, is not intuitively reasonable in the case of this study. Finally, using a $\mathrm{RE}$ model also allows me to control for other time-invariant characteristics such as gender and test alternative hypotheses. 


\subsection{Main Results}

We start the analysis in Table 2 which presents the main results in this paper. The basic specification includes standard socio-demographic controls for age, age squared, sex, marital status, employment status, log of personal labor income, and regional and year fixed-effects. All regressions are estimated using a random-effects estimator with robust standard errors clustered at the individual level.

The main finding in this table is that people with higher education are more likely to report higher levels of life satisfaction, eudaimonic, and hedonic SWB (models 1-3). The results in model 4 and 5 furthermore suggest that more educated people tend to experience more positive affect and less negative affect in their day to day lives. Finally, model 6 shows that education is negatively correlated with psychological distress (the summary measure from the Kessler Psychological Distress Scale). The coefficient on education is statistically significant in all models, although it is significant only at the 10 percent level in model 1 where the dependent variable is life satisfaction.

[Table 2 around here]

The rest of the coefficients in most estimations also have the expected signs and are statistically significant which provides confidence in the foundations of the model. For example, the relationship between happiness and age is found to be non-linear with the least happy years occurring around the age of 40, and with women, married, employed, and richer people reporting higher levels of SWB.

To better understand the magnitude of these relationships, Figure 1 shows the average predicted value for each one of the SWB measures of interest while holding constant the other socio-demographic controls in the model at their sample means. The shaded areas in this figure represent 95 percent confidence intervals for the predictions. The relationship between higher education and SWB displays a strong and significant correlation in all graphs with the exception of life satisfaction. The "average" person, ${ }^{4}$ for example, who has only a college degree will report virtually the same level of life satisfaction as their less educated

\footnotetext{
${ }^{4}$ By average here I utilize the common, although not universal practice, of using the mean values for all independent variables in the model.
} 
counterpart who has only a high school degree. The effect, however, appears to be far more substantial when it comes to eudaimonic and hedonic SWB. The average person with a college degree will report eudaimonic SWB score of close to 4.6 (on a scale from 1 to 5) while a person with only 8 years of education will score a little over 4.3 , a difference of close to one half of a standard deviation in the dependent variable. To put this in perspective, the effect of one additional year of schooling is twice as strong as the negative effect from personal unemployment. The other four graphs display similar patterns.

\subsection{Decomposing the Hedonic and Eudaimonic Indexes}

Next, to get even more detailed picture on the relationship between higher education and SWB, I decompose the two indexes on hedonic and eudaimonic SWB into their more specific measures and re-estimate the main model from Table 2. The results, which are presented in Table 3, suggest that people with lower education tend to report being more worthless and hopeless about their lives. They also report less positive engagement in their daily activities-they are more likely to be tired for no particular reason and to believe that most of what they do in life is an effort. On the hedonic side, better educated people are less likely to report being said, fidgety, restless and not being able to calm down. However, more educated people are also more likely to report feeling nervous.

[Table 3 around here]

The coefficients on all SWB variables are statistically significant at the 0.000 level and the magnitude of the relationships are similar to the ones suggested in Table 2.

\subsection{Domain Satisfactions}

Next, following the approach proposed by Van Praag et al. (2003), I examine how higher education is associated with ten different domain satisfactions. This approach has previously been in the context of self-employment (Binder and Coad, 2013). The results, which are summarized in Table 4, suggest that people with higher education report higher satisfaction in most life domains. For example, better educated people are more likely to be satisfied with their employment opportunities and financial situation. They are also more likely 
to report higher satisfaction with the neighborhoods they live, being part of their local community, how safe they feel, and the relationship of their children at home. This is consistent with the discussion in section 2. Nevertheless, the results in this table also point out that more educated people report lower life satisfaction with the amount of free time they have and the home they live in.

[Table 4 around here]

\subsection{Results by Gender}

Table 5 presents the re-estimation of the main model by gender. The main findings of this table suggest that the SWB benefits from a higher degree tend to be higher for women. This is especially true for the measures of eudaimonic and hedonic SWB. The estimated coefficient for hednic SWB, for example, has a 50 percent larger magnitude. This observation might help explain the difference in educational attainment between genders that has shifted over the past few decades. In 1980, for example, there was virtually no difference in the high school completion rate between females (86 percent) and males (86 percent), but in 2011 the percentage of females with a high school diploma (91 percent) was higher by four percentage points than males (87 percent) for the United States. Similarly, in 1980 the percentage of females (21 percent) with a college degree was three percentage points lower than males (24 percent), but by 2011 significantly more females (36 percent) were graduating college than males (28 percent). Across the OECD countries, for examples, women with university level degrees are also twice as likely to find a job as are men (OECD, 2012).

\subsection{Robustness Check}

As a robustness check, I first re-estimate my main model using instead of years of education, a recoded variable that measures five levels of education attainment-less than high school, high school, some college, college, and graduate degree. The so called sheepskin effect proposes that what matters when it comes to formal education is not the number of additional years of schooling, but the degree (or certification) that an individual completes. Table 6, then, presents the results from such estimations. The results are consistent with 
the main findings so far. They also more clearly show that the positive SWB effect from higher education is increasing, but at a decreasing rate. For example, the coefficients on educational attainment from model 2 imply that a high school degree (compared to less than high school dimploma) increases eidaimonic happiness with close to 0.1 points while the coefficient on college is only .082 points higher compared to that of a high school degree. The coefficients on college degree and graduate diploma suggest virtually the same SWB premium from college and graduate school compared to less than a high school degree. Similar patterns emerge with respect to the other SWB measures in the table.

[Table 6 around here]

As another robustness check, I re-estimate the main model in Table 2 by adding additional controls for health and exercise habits as well as the big five personality traitsagreeableness, conscientiousness, emotional stability, extroversion, and openness. These results are reported in Table 7 and significantly limit my sample since the variables on personality are available only for three years. Even after controlling for these additional variables, however, I still find that people with higher education are more likely to report higher levels of eudaimonic and hedonic SWB. They are significantly less likely to report negative feelings and have psychological distress in their daily lives. However, once I control for these additional variables, the coefficients on life satisfaction and positive affect become negative and significant. This suggests that much of the positive effect on life satisfaction and positive emotions is likely associated with better health and exercise habits or linked to people's personality.

[Table 7 around here]

\section{Concluding Remarks}

An increasing number of studies have documented an insignificant or negative relationship between higher education and subjective well-being. Majority of these previous studies, however, use life satisfaction as a proxy for SWB. In this study, I contribute to this line of research by evaluating the relationship between higher education and three separate 
measures of SWB: (1) evaluative, (2) hedonic, and (3) eudaimonic. I also examine the relationship between higher education and 10 different life domain satisfactions.

Three substantial results emerge: (1) people with higher education are more likely to report higher levels of eudaimonic and hedonic SWB, i.e., they view their lives as more meaningful and experience more positive emotions and less negative ones; (2) people with higher education are satisfied with most life domains (financial, employment opportunities, neighborhood, local community, children at home) but they consistently report lower satisfaction with the amount of free time they have; (3) the positive effect of higher education is increasing, but at a decreasing rate; the SWB gains from obtaining a graduate degree are much lower (on the margin) compared to getting a college degree.

These results shed light on some of the previous contradictory empirical findings in the literature and suggest that higher education has large SWB returns, especially when it comes to eudaimonic and hedonic happiness. The findings also suggest one possible reason why more educated people report lower levels of life satisfaction-while people with higher degrees have more fulfilling and meaningful jobs, they also have less time to enjoy other aspects of their lives. Finally, the results in this study point to important trade-offs between these three different types of SWB that people could be making when choosing to go to college.

\section{Bibliography}

Albert, C. and Davia, M. A. (2005). Education, wages and job satisfaction. In Epunet conference. Citeseer.

Alwin, D. F. (1991). Family of origin and cohort differences in verbal ability. American Sociological Review, pages 625-638.

Becker, G. S. (1973). A theory of marriage: Part i. The Journal of Political Economy, pages 813-846. 
Becker, G. S. (2009). Human capital: A theoretical and empirical analysis, with special reference to education. University of Chicago Press.

Binder, M. and Coad, A. (2013). Life satisfaction and self-employment: a matching approach. Small Business Economics, 40(4):1009-1033.

Blanchflower, D. G. and Oswald, A. J. (2004). Well-being over time in britain and the usa. Journal of Public Economics, 88(7):1359-1386.

Blanchflower, D. G., Oswald, A. J., and Sanfey, P. (1992). Wages, profits and rent-sharing. Technical report, National Bureau of Economic Research.

Brist, L. E. and Caplan, A. J. (1999). More evidence on the role of secondary education in the development of lower-income countries: Wishful thinking or useful knowledge? Economic Development and Cultural Change, 48(1):155-175.

Cameron, A. C. and Trivedi, P. K. (2009). Microeconomics using stata. College Station, TX: Stata Press Publications.

Card, D. (1999). The causal effect of education on earnings. Handbook of Labor Economics, $3: 1801-1863$.

Cascio, E. U. and Lewis, E. G. (2006). Schooling and the armed forces qualifying test evidence from school-entry laws. Journal of Human Resources, 41(2):294-318.

Chiappori, P.-A., Iyigun, M., and Weiss, Y. (2009). Investment in schooling and the marriage market. American Economic Review, 99(5):1689-1713.

Clark, A. and Oswald, A. (1995). Satisfaction and comparison income. Journal of Public Economics, 61:359-381.

Clark, A. E. (2016). Swb as a measure of individual well-being. Handbook of Well-being and Public Policy, forthcoming.

Clark, A. E. and Oswald, A. J. (1994). Unhappiness and unemployment. The Economic Journal, 104(424):648-659.

Cuñado, J. and de Gracia, F. P. (2012). Does education affect happiness? evidence for spain. Social Indicators Research, 108(1):185-196.

Cunha, F. and Heckman, J. J. (2009). The economics and psychology of inequality and human development. Journal of the European Economic Association, 7(2-3):320-364. 
Cutler, D. M. and Lleras-Muney, A. (2006). Education and health: evaluating theories and evidence. Technical report, National Bureau of Economic Research.

Deci, E. L. and Ryan, R. M. (2002). Handbook of Self-determination Research. University Rochester Press.

Dee, T. S. (2004). Are there civic returns to education? Journal of Public Economics, 88(9):1697-1720.

Di Tella, R. and MacCulloch, R. (2006). Some uses of happiness data in economics. The Journal of Economic Perspectives, 20(1):25-46.

Di Tella, R., MacCulloch, R. J., and Oswald, A. J. (2003). The macroeconomics of happiness. Review of Economics and Statistics, 85(4):809-827.

Diener, E., Lucas, R. E., and Oishi, S. (2002). Subjective well-being. Handbook of Positive Psychology, pages 63-73.

Ferrer-i Carbonell, A. and Frijters, P. (2004). How important is methodology for the estimates of the determinants of happiness?*. The Economic Journal, 114(497):641-659.

Frey, B. S. and Stutzer, A. (2002). What can economists learn from happiness research? Journal of Economic Literature, 40(2):402-435.

Frey, B. S. and Stutzer, A. (2010). Happiness and economics: How the economy and institutions affect human well-being. Princeton University Press.

Green, D. A. and Riddell, W. C. (2003). Literacy and earnings: an investigation of the interaction of cognitive and unobserved skills in earnings generation. Labour Economics, 10(2):165-184.

Green, F. (2011). Unpacking the misery multiplier: How employability modifies the impacts of unemployment and job insecurity on life satisfaction and mental health. Journal of Health Economics, 30(2):265-276.

Grogger, J. (1997). Local violence and educational attainment. Journal of Human Resources, pages 659-682.

Grossman, M. (2006). Education and nonmarket outcomes. Handbook of the Economics of Education, 1:577-633.

Heckman, J. J., Lochner, L. J., and Todd, P. E. (2006). Earnings functions, rates of return 
and treatment effects: The mincer equation and beyond. Handbook of the Economics of Education, 1:307-458.

Helliwell, J. F. and Putnam, R. D. (2007). Education and social capital. Eastern Economic Journal, 33(1):1-19.

Helliwell, J. F., Putnam, R. D., et al. (2004). The social context of well-being. Philosophical transactions-royal society of London series B biological sciences, pages 1435-1446.

Inglehart, R., Foa, R., Peterson, C., and Welzel, C. (2008). Development, freedom, and rising happiness: A global perspective (1981-2007). Perspectives on Psychological Science, $3(4): 264-285$

Jones, L. E., Schoonbroodt, A., and Tertilt, M. (2008). Fertility theories: can they explain the negative fertility-income relationship? Technical report, National Bureau of Economic Research

Kahneman, D. and Deaton, A. (2010). High income improves evaluation of life but not emotional well-being. Proceedings of the National Academy of Sciences, 107(38):1648916493

Kahneman, D. and Krueger, A. B. (2006). Developments in the measurement of subjective well-being. The Journal of Economic Perspectives, 20(1):3-24.

Kessler, R. C. and Mroczek, D. K. (1995). Measuring the effects of medical interventions. Medical Care, pages AS109-AS119.

Klein, S. M. and Maher, J. (1966). Education level and satisfaction with pay. Personnel Psychology, 19(2):195-208.

Layard, P. R. and Layard, R. (2011). Happiness: Lessons from a new science. Penguin UK.

Layard, R., Mayraz, G., and Nickell, S. (2008). The marginal utility of income. Journal of Public Economics, 92(8):1846-1857.

Leigh, J. P. (1998). Parents' schooling and the correlation between education and frailty. Economics of Education Review, 17(3):349-358.

Li, M. (2006). High school completion and future youth unemployment: New evidence from high school and beyond. Journal of Applied Econometrics, 21(1):23-53.

Machin, S., Salvanes, K. G., and Pelkonen, P. (2012). Education and mobility. Journal of the European Economic Association, 10(2):417-450. 
Maslow, A. H. (1943). A theory of human motivation. Psychological Review, 50(4):370.

Mincer, J. (1974). Schooling, earnings and experience.

Mirowsky, J. and Ross, C. E. (2003). Education, social status, and health. Transaction Publishers.

Nikolaev, B. (2015). Living with mom and dad and loving it...or are you? Journal of Economic Psychology, 51:199-209.

Nikolaev, B. (2016). Does other people's education make us less happy? Economics of Education Review, 52(2):176-191.

Nikolaev, B. and Rusakov, P. (2015). Education and happiness: an alternative hypothesis. Applied Economics Letters, pages 1-4.

OECD (2012). OECD Factbook 2011-2012: Economic, Environmental and Social Statistics. OECD.

Oreopoulos, P. and Salvanes, K. G. (2011). Priceless: The nonpecuniary benefits of schooling. Journal of Economic Perspectives, 25(1):159-184.

Pink, D. H. (2011). Drive: The surprising truth about what motivates us. Penguin.

Powdthavee, N. (2010). How much does money really matter? estimating the causal effects of income on happiness. Empirical Economics, 39(1):77-92.

Powdthavee, N., Lekfuangfu, W. N., and Wooden, M. (2015). What's the good of education on our overall quality of life? a simultaneous equation model of education and life satisfaction for australia. Journal of Behavioral and Experimental Economics, 54:10-21.

Qari, S. (2010). Marriage, adaptation and happiness: Are there long-lasting gains to marriage? Journal of Socio-Economics.

Ross, C. E. and Wu, C.-l. (1995). The links between education and health. American Sociological Review, pages 719-745.

Sacks, D. W., Stevenson, B., and Wolfers, J. (2010). Subjective well-being, income, economic development and growth. Technical report, National Bureau of Economic Research.

Seligman, M. E. (2012). Flourish: A visionary new understanding of happiness and wellbeing. Simon and Schuster.

Shields, M. A., Price, S. W., and Wooden, M. (2009). Life satisfaction and the economic and 
social characteristics of neighbourhoods. Journal of Population Economics, 22(2):421443.

Stiglitz, J. E., Sen, A., and Fitoussi, J.-P. (2009). Report by the commission on the measurement of economic performance and social progress.

Van Praag, B. M. and Ferrer-i Carbonell, A. (2008). Happiness quantified: A satisfaction calculus approach. Oxford University Press.

Van Praag, B. M., Frijters, P., and Ferrer-i Carbonell, A. (2003). The anatomy of subjective well-being. Journal of Economic Behavior \& Organization, 51(1):29-49.

Veenhoven, R. (2010). Capability and happiness: Conceptual difference and reality links. The Journal of Socio-Economics, 39(3):344-350.

Verme, P. (2009). Happiness, freedom and control. Journal of Economic Behavior E6 Organization, 71(2):146-161.

Warr, P. (1992). Age and occupational well-being. Psychology and Aging, 7(1):37.

Watson, N. and Wooden, M. P. (2012). The hilda survey: a case study in the design and development of a successful household panel survey. Longitudinal and Life Course Studies, 3(3):369-381.

Weisbrod, B. A. (1962). Education and investment in human capital. In Investment in Human Beings, pages 106-123. The Journal of Political Economy Vol. LXX, No. 5, Part 2 (University of Chicago Press).

White, L. K., Booth, A., and Edwards, J. N. (1986). Children and marital happiness why the negative correlation? Journal of Family Issues, 7(2):131-147.

Yamada, T., Yamada, T., and Kang, J. M. (1991). Crime rates versus labor market conditions; theory and time-series evidence. Technical report, National Bureau of Economic Research. 


\section{Appendix}

Table 1: Summary Statistics

\begin{tabular}{|c|c|c|c|c|c|}
\hline Variable & Obs & Mean & Std. Dev. & Min & Max \\
\hline Life Satisfaction & 182663 & 7.91 & 1.49 & O & 10 \\
\hline \multicolumn{6}{|l|}{ Domain Satisfactions (DS) } \\
\hline Employment Opportunities & 145,835 & 7.00 & 2.41 & o & 10 \\
\hline Financial & 182,576 & 6.40 & 2.28 & o & 10 \\
\hline Amount of Free Time & 182,580 & 6.68 & 2.53 & o & 10 \\
\hline Home You Live & 182,613 & 7.96 & 1.86 & O & 10 \\
\hline Local Community & 182,427 & 6.73 & 2.20 & O & 10 \\
\hline Neighborhood You Live & 182,540 & 7.88 & 1.77 & o & 10 \\
\hline How Safe You Feel & 182,631 & 8.15 & 1.65 & O & 10 \\
\hline Relationship w Children & 106,785 & 8.42 & 1.87 & o & 10 \\
\hline Relationship w Partner & 115,879 & 8.26 & 2.06 & O & 10 \\
\hline Children in Household & 47,882 & 5.96 & 3.42 & O & 10 \\
\hline Eudaimonic & 52966 & 4.49 & 0.72 & 1 & 5 \\
\hline Worthless & 53,182 & 4.65 & 0.77 & 1 & 5 \\
\hline Tired for No Good Reason & 53,182 & 4.65 & 0.77 & 1 & 5 \\
\hline Everything an Effort & 53,148 & 4.22 & 0.93 & 1 & 5 \\
\hline Hopeless & 53,125 & 4.59 & 0.78 & 1 & 5 \\
\hline Hedonic & 52624 & 4.41 & 0.61 & 1 & 5 \\
\hline Feeling Sad & 53,173 & 4.65 & 0.73 & 1 & 5 \\
\hline Feeling Restless or Fidgety & 53,130 & 4.29 & 0.86 & 1 & 5 \\
\hline Feeling Nervous & 53,129 & 4.17 & 0.88 & 1 & 5 \\
\hline Cannot Sit Still & 53,120 & 4.66 & 0.71 & 1 & 5 \\
\hline Cannot Calm Down & 53,128 & 4.75 & 0.62 & 1 & 5 \\
\hline Positive Affect & 161707 & 4.21 & 1.04 & 1 & 6 \\
\hline Been a Happy Person & 162,278 & 4.43 & 1.08 & 1 & 6 \\
\hline Felt Calm and Peaceful & 162,267 & 3.98 & 1.22 & 1 & 6 \\
\hline Negative Affect & 159899 & 2.32 & 0.85 & 1 & 6 \\
\hline Been a Nervous Person & 162,388 & 2.04 & 1.11 & 1 & 6 \\
\hline Nothing Could Cheer You Up & 162,095 & 1.65 & 1.02 & 1 & 6 \\
\hline Felt Down & 162,080 & 2.15 & 1.06 & 1 & 6 \\
\hline Felt Worn Out & 161,732 & 2.70 & 1.16 & 1 & 6 \\
\hline Felt Tired & 162,443 & 3.08 & 1.16 & 1 & 6 \\
\hline Psych Distress Scale & 53235 & $15 \cdot 72$ & 6.30 & 10 & 50 \\
\hline Education & 180292 & 12.01 & 2.58 & o & 18.5 \\
\hline Age & 182799 & 43.95 & $18.5^{2}$ & 14 & 101 \\
\hline Age Squared & 182799 & 2.27 & 1.78 & 0.20 & 10.20 \\
\hline Female & 182799 & 0.53 & 0.50 & o & 1 \\
\hline \multicolumn{6}{|l|}{ Marital Status (Base $=$ Married) } \\
\hline Single & 182697 & 0.24 & 0.43 & o & 1 \\
\hline Widowed & 182697 & 0.05 & 0.22 & o & 1 \\
\hline Divorced & 182697 & 0.06 & 0.24 & o & 1 \\
\hline Separated & 182697 & 0.03 & 0.16 & o & 1 \\
\hline \multicolumn{6}{|l|}{ Employment Status (Base = Employed) } \\
\hline Employed & 182799 & 0.59 & 0.49 & o & 1 \\
\hline \multirow{2}{*}{\multicolumn{6}{|c|}{ Health (Base=Poor) }} \\
\hline & & & & & \\
\hline Fair & 161527 & 0.14 & 0.34 & o & 1 \\
\hline Good & 161527 & 0.35 & 0.48 & $\mathrm{O}$ & 1 \\
\hline Very Good & 161527 & 0.36 & 0.48 & o & 1 \\
\hline Excellent & 161527 & 0.12 & 0.32 & o & 1 \\
\hline \multicolumn{6}{|l|}{ Exercise [Base=Almost Never $]$} \\
\hline Less than weekly & 162813 & 0.15 & 0.36 & o & 1 \\
\hline Weekly & 162813 & 0.73 & 0.44 & o & 1 \\
\hline Region Dummies & 182788 & & & o & 1 \\
\hline Year Dummies & 182788 & & & $\mathrm{O}$ & 1 \\
\hline
\end{tabular}

Source: HILDA (2001-2013), Authors' calculations. 
Table 2: Main Results, Subjective Well-being and Education

\begin{tabular}{|c|c|c|c|c|c|c|}
\hline & $\begin{array}{c}(1) \\
\text { Life Satisfaction }\end{array}$ & $\begin{array}{c}(2) \\
\text { Eudaimonic } \\
\end{array}$ & $\begin{array}{c}\text { (3) } \\
\text { Hedonic }\end{array}$ & $\begin{array}{c}\text { (4) } \\
\text { Positive Affect }\end{array}$ & $\begin{array}{c}\text { (5) } \\
\text { Negative Affect }\end{array}$ & $\begin{array}{c}(6) \\
\text { Distress Scale }\end{array}$ \\
\hline Education & $\begin{array}{c}0.00717^{*} \\
(0.00382)\end{array}$ & $\begin{array}{l}0.0265^{* * *} \\
(0.00226)\end{array}$ & $\begin{array}{l}0.0284^{* * *} \\
(0.00195)\end{array}$ & $\begin{array}{l}0.0221^{* * *} \\
(0.00254)\end{array}$ & $\begin{array}{l}-0.0331^{* * *} \\
(0.00215)\end{array}$ & $\begin{array}{l}-0.283^{* * *} \\
(0.0200)\end{array}$ \\
\hline Age & $\begin{array}{c}-0.0664^{* * *} \\
(0.00431)\end{array}$ & $\begin{array}{l}-0.0119^{* * *} \\
(0.00306)\end{array}$ & $\begin{array}{l}-0.00369 \\
(0.00258)\end{array}$ & $\begin{array}{l}-0.0370^{* * *} \\
(0.00302)\end{array}$ & $\begin{array}{c}0.00676^{* * * *} \\
(0.00249)\end{array}$ & $\begin{array}{l}0.0657^{* *} \\
(0.0265)\end{array}$ \\
\hline Age Squared & $\begin{array}{l}0.809^{* * * *} \\
(0.0501)\end{array}$ & $\begin{array}{l}0.202^{* * *} \\
(0.0350)\end{array}$ & $\begin{array}{l}0.105^{* * *} \\
(0.0296)\end{array}$ & $\begin{array}{l}0.454^{* * *} \\
(0.0352)\end{array}$ & $\begin{array}{c}-0.170^{* * * *} \\
(0.0288)\end{array}$ & $\begin{array}{c}-1.374^{* * *} \\
(0.304)\end{array}$ \\
\hline Female & $\begin{array}{l}0.138^{* * *} \\
(0.0171)\end{array}$ & $\begin{array}{c}-0.0696^{* * *} \\
(0.0105)\end{array}$ & $\begin{array}{c}-0.0437^{* * *} \\
(0.00902)\end{array}$ & $\begin{array}{c}-0.0650^{* * *} \\
(0.0124)\end{array}$ & $\begin{array}{l}0.153^{* * *} \\
(0.0104)\end{array}$ & $\begin{array}{l}0.546^{* * * *} \\
(0.0933)\end{array}$ \\
\hline Single & $\begin{array}{c}-0.409^{* * * *} \\
(0.0187)\end{array}$ & $\begin{array}{l}-0.134^{* * *} \\
(0.0145)\end{array}$ & $\begin{array}{l}-0.123^{* * *} \\
(0.0117)\end{array}$ & $\begin{array}{l}-0.117^{* * * *} \\
(0.0138)\end{array}$ & $\begin{array}{l}0.0716^{* * * *} \\
(0.0115)\end{array}$ & $\begin{array}{l}1.339^{* * *} \\
(0.122)\end{array}$ \\
\hline Widowed & $\begin{array}{l}-0.457^{* * *} \\
(0.0818)\end{array}$ & $\begin{array}{l}-0.131^{* * *} \\
(0.0428)\end{array}$ & $\begin{array}{l}-0.138^{* * *} \\
(0.0413)\end{array}$ & $\begin{array}{c}-0.155^{* * *} \\
(0.0476)\end{array}$ & $\begin{array}{l}0.131^{* * *} \\
(0.0401)\end{array}$ & $\begin{array}{c}1.509^{* * *} \\
(0.409)\end{array}$ \\
\hline Divorced & $\begin{array}{c}-0.519^{* * *} \\
(0.0313)\end{array}$ & $\begin{array}{c}-0.165^{* * *} \\
(0.0221)\end{array}$ & $\begin{array}{c}-0.135^{* * * *} \\
(0.0182)\end{array}$ & $\begin{array}{c}-0.0831^{* * *} \\
(0.0204)\end{array}$ & $\begin{array}{l}0.0982^{* * *} \\
(0.0168)\end{array}$ & $\begin{array}{c}1.508^{* * * *} \\
(0.192)\end{array}$ \\
\hline Separated & $\begin{array}{c}-0.761^{* * *} \\
(0.0345)\end{array}$ & $\begin{array}{l}-0.244^{* * *} \\
(0.0284)\end{array}$ & $\begin{array}{l}-0.190^{* * * *} \\
(0.0226)\end{array}$ & $\begin{array}{l}-0.224^{* * *} \\
(0.0223)\end{array}$ & $\begin{array}{l}0.196^{* * *} \\
(0.0178)\end{array}$ & $\begin{array}{l}2.217^{* * *} \\
(0.240)\end{array}$ \\
\hline Employed & $\begin{array}{c}0.0291 \\
(0.0183)\end{array}$ & $\begin{array}{l}0.0411^{* * *} \\
(0.0123)\end{array}$ & $\begin{array}{c}0.0161^{*} \\
(0.00957)\end{array}$ & $\begin{array}{c}0.0150 \\
(0.0126)\end{array}$ & $\begin{array}{c}-0.0387^{* * *} \\
(0.0102)\end{array}$ & $\begin{array}{c}-0.279^{* * *} \\
(0.0997)\end{array}$ \\
\hline Log Labor Income & $\begin{array}{c}0.00909^{* * *} \\
(0.00199)\end{array}$ & $\begin{array}{l}0.0130^{* * *} \\
(0.00141)\end{array}$ & $\begin{array}{c}0.00921^{* * *} \\
(0.00111)\end{array}$ & $\begin{array}{c}0.00676^{* * *} \\
(0.00138)\end{array}$ & $\begin{array}{l}-0.00510^{* * * *} \\
(0.00112)\end{array}$ & $\begin{array}{c}-0.102^{* * *} \\
(0.0116)\end{array}$ \\
\hline Regional FE & YES & YES & YES & YES & YES & YES \\
\hline Year FE & YES & YES & YES & YES & YES & YES \\
\hline R2 between & 0.0746 & 0.0791 & 0.0791 & 0.0321 & 0.0684 & 0.0863 \\
\hline R2 within & 0.0124 & 0.00274 & 0.00189 & 0.00311 & 0.00414 & 0.00297 \\
\hline $\mathrm{N}$ Individuals & 20143 & 14254 & 14228 & 18992 & 18951 & 14267 \\
\hline N Observations & 126265 & 36370 & 36194 & 112603 & 111582 & 36504 \\
\hline
\end{tabular}

reported in parentheses. All models are estimated with a random effects model and include regional and year (wave) fixed effects. The

categories male and married are used as base categories. Statistical significance reported: ${ }^{* * *} \mathrm{p}<0.01,{ }^{* *} \mathrm{p}<0.05,{ }^{*} \mathrm{p}<0.1$ 
Figure 1: Subjective Well-being and Education, Predicted Values
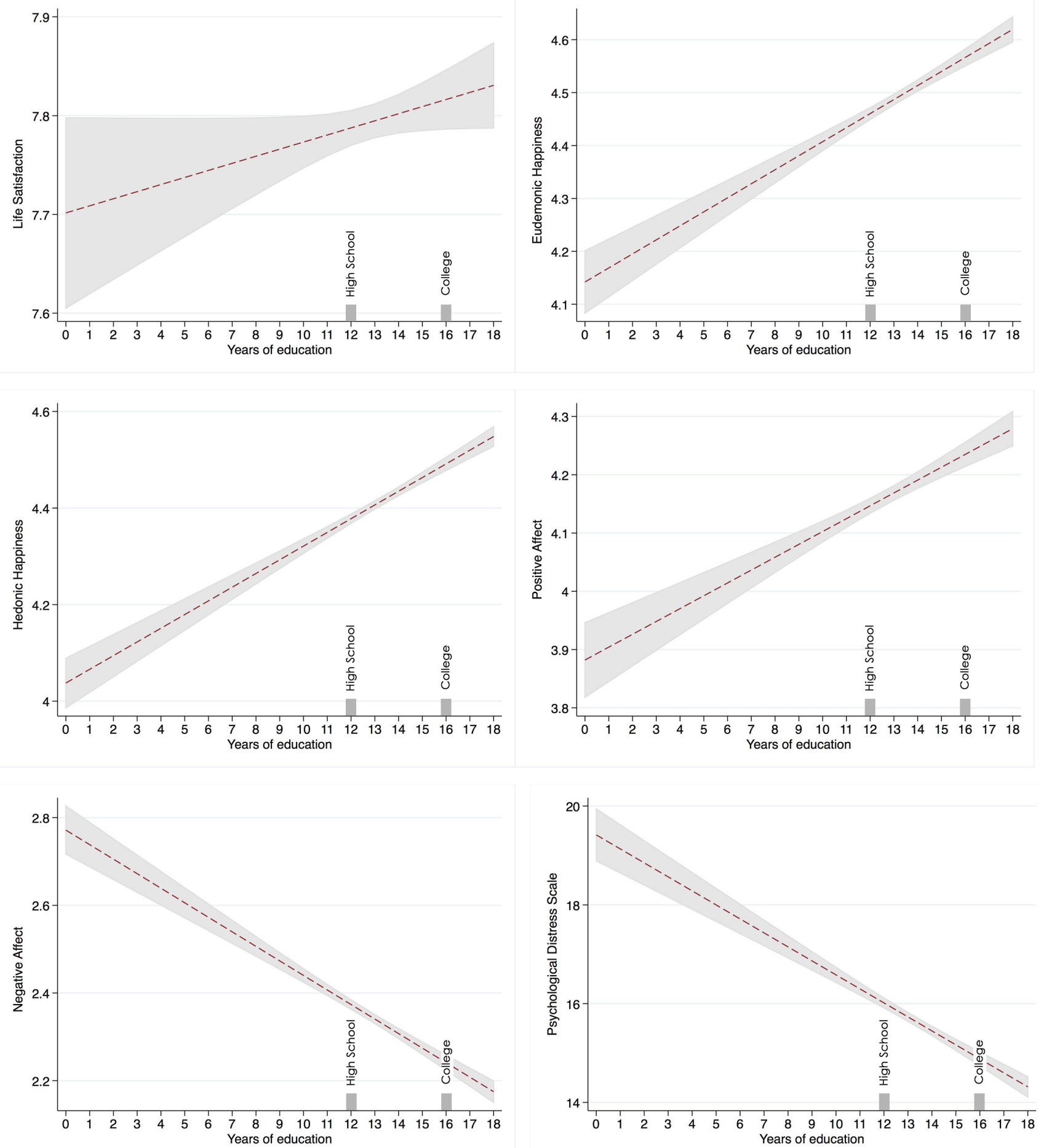
Table 3: Decomposing Hedonic and Eudemonic Indexes

\begin{tabular}{|c|c|c|c|c|c|c|c|c|c|}
\hline \multicolumn{5}{|c|}{ Eudaimonic } & \multicolumn{5}{|c|}{ Hedonic } \\
\hline & Worthless & Hopeless & $\begin{array}{l}\text { Everything } \\
\text { Effort }\end{array}$ & Tired & Sad & Fidgety & Nervous & Restless & Can't Calm Down \\
\hline Education & $\begin{array}{c}-0.0281^{* * *} \\
(0.00239)\end{array}$ & $\begin{array}{r}-0.0261^{* * *} \\
(0.00239)\end{array}$ & $\begin{array}{c}-0.0209^{* * *} \\
(0.00279)\end{array}$ & $\begin{array}{c}-0.0281^{* * *} \\
(0.00239)\end{array}$ & $\begin{array}{c}-0.0288^{* * * *} \\
(0.00222)\end{array}$ & $\begin{array}{c}-0.0203^{* * *} \\
(0.00254)\end{array}$ & $\begin{array}{l}0.0131^{* * *} \\
(0.00266)\end{array}$ & $\begin{array}{c}-0.0320^{* * *} \\
(0.00211)\end{array}$ & $\begin{array}{c}-0.0215^{* * *} \\
(0.00195)\end{array}$ \\
\hline Controls & YES & YES & YES & YES & YES & YES & YES & YES & YES \\
\hline Regional FE & YES & YES & YES & YES & YES & YES & YES & YES & YES \\
\hline Year FE & YES & YES & YES & YES & YES & YES & YES & YES & YES \\
\hline R2 between & 0.0695 & 0.0764 & 0.0572 & 0.0695 & 0.0766 & 0.0547 & 0.0546 & 0.0622 & 0.065 \\
\hline R2 within & 0.00177 & 0.00322 & 0.000504 & 0.00177 & 0.00288 & 0.00133 & 0.00105 & 0.000422 & 0.000602 \\
\hline $\mathrm{N}$ Individuals & 14262 & 14265 & 14265 & 14262 & 14262 & 14258 & 14264 & 14262 & 14261 \\
\hline $\begin{array}{l}\mathrm{N} \\
\text { Observations }\end{array}$ & 36480 & 36447 & 36459 & 36480 & 36468 & 36453 & 36450 & 36448 & 36443 \\
\hline
\end{tabular}

Notes: Data HILDA, 2001-2013. Sample includes individuals aged 22-65 years old. Robust standard errors clustered at the individual level reported in parentheses. All models are estimated with a random effects model and include regional and year (wave) fixed effects. The categories male and married are used as base categories. Statistical significance reported: ${ }^{* * *} \mathrm{p}<0.01,{ }^{* *} \mathrm{p}<0.05,{ }^{*} \mathrm{p}<0.1$ 
Table 4: Domain Satisfactions

\begin{tabular}{|c|c|c|c|c|c|c|c|c|}
\hline Domain Satisfaction & Education & (St. error) & Controls & Regional/Year FE & R2 between & R2 within & Individuals & $\mathrm{N}$ \\
\hline Life Satisfaction & $0.00717^{*}$ & $(0.00382)$ & YES & YES & 0.0746 & 0.0124 & 20143 & 126265 \\
\hline Employment Opportunities & $0.0802^{* * *}$ & $(0.00603)$ & YES & YES & 0.251 & 0.0298 & 18150 & 100418 \\
\hline Financial Satisfaction & $0.0893^{* * *}$ & $(0.00548)$ & YES & YES & 0.189 & 0.0331 & 18977 & 111807 \\
\hline Amount of Free Time & $-0.0349^{* * *}$ & $(0.00582)$ & YES & YES & 0.103 & 0.0181 & 18976 & 111783 \\
\hline The Home You Live & $-0.00888^{* *}$ & $(0.00431)$ & YES & YES & 0.0795 & 0.00479 & 18973 & 111771 \\
\hline Part of Local Community & $0.0310^{* * *}$ & $(0.00520)$ & YES & YES & 0.0945 & 0.0101 & 18973 & 111716 \\
\hline Neighborhood & $0.0126^{* * *}$ & $(0.00420)$ & YES & YES & 0.102 & 0.0100 & 18971 & 111736 \\
\hline How Safe You Feel & $0.0226^{* * *}$ & $(0.00416)$ & YES & YES & 0.114 & 0.0136 & 18977 & 111788 \\
\hline Relationship with Children & -0.000367 & $(0.00586)$ & YES & YES & 0.0978 & 0.0238 & 13567 & 80732 \\
\hline Relationship with Partner & -0.00746 & $(0.00560)$ & YES & YES & 0.180 & 0.0563 & 16266 & 89389 \\
\hline Children in Household & $0.0409^{* * *}$ & $(0.00723)$ & YES & YES & 0.0469 & 0.0164 & 10822 & 51912 \\
\hline
\end{tabular}


Table 5: Main Results by Gender

\begin{tabular}{|c|c|c|c|c|c|c|c|c|c|}
\hline & Education & St. Error & Controls & Regional FE & Year FE & R2 between & R2 within & Individuals & $\mathrm{N}$ \\
\hline \multicolumn{10}{|l|}{ Male } \\
\hline Life Satisfaction & 0.00313 & $(0.00583)$ & YES & YES & YES & 0.0789 & 0.0137 & 9803 & 59963 \\
\hline Eudemonic & $0.0243^{* * *}$ & $(0.00324)$ & YES & YES & YES & 0.0815 & 0.00385 & 6748 & 17020 \\
\hline Hedonic & $0.0239^{* * *}$ & (0.00288) & YES & YES & YES & 0.0772 & 0.00260 & 6734 & 16948 \\
\hline Pos Affect & $0.0219^{* * *}$ & $(0.00376)$ & YES & YES & YES & 0.0386 & 0.00410 & 9157 & 52778 \\
\hline Neg Affect & $-0.0345^{* * *}$ & $(0.00306)$ & YES & YES & YES & 0.0597 & 0.00439 & 9138 & 52345 \\
\hline Psych Distress & $-0.244^{* * *}$ & (0.0293) & YES & YES & YES & 0.0858 & 0.00419 & 6755 & 17070 \\
\hline \multicolumn{10}{|l|}{ Female } \\
\hline Life Satisfaction & $0.0125^{* *}$ & $(0.00508)$ & YES & YES & YES & 0.0715 & 0.0122 & 10340 & 66302 \\
\hline Eudemonic & $0.0291^{* * *}$ & $(0.00316)$ & YES & YES & YES & 0.0732 & 0.00218 & 7506 & 19350 \\
\hline Hedonic & $0.0326^{* * *}$ & $(0.00268)$ & YES & YES & YES & 0.0807 & 0.00174 & 7494 & 19246 \\
\hline Pos Affect & $0.0229^{* * *}$ & $(0.00347)$ & YES & YES & YES & 0.0259 & 0.00264 & 9835 & 59825 \\
\hline Neg Affect & $-0.0333^{* * *}$ & $(0.00303)$ & YES & YES & YES & 0.0599 & 0.00458 & 9813 & 59237 \\
\hline Psych Distress & $-0.322^{* * *}$ & (0.0276) & YES & YES & YES & 0.0846 & 0.00256 & 7512 & 19434 \\
\hline
\end{tabular}

Notes: Data HILDA, 2001-2013. Sample includes individuals aged 22-65 years old. Robust standard errors clustered at the individual level reported in parentheses. All models are estimated with a random effects model and include regional and year (wave) fixed effects. The categories male and married are used as base categories. Statistical significance reported: ${ }^{* * *} \mathrm{p}<0.01,{ }^{* *} \mathrm{p}<0.05,{ }^{*} \mathrm{p}<0.1$ 
Table 6: Main Results by Educational Attainment (Degree)

\begin{tabular}{|c|c|c|c|c|c|c|}
\hline & Life Satisfaction & Eudemonic & Hedonic & Pos Affect & Neg Affect & Psych Distress \\
\hline High School & $\begin{array}{l}-0.0189 \\
(0.0233)\end{array}$ & $\begin{array}{c}0.0917^{* * *} \\
(0.0154)\end{array}$ & $\begin{array}{l}0.103^{* * *} \\
(0.0131)\end{array}$ & $\begin{array}{c}0.0638^{* * *} \\
(0.0156)\end{array}$ & $\begin{array}{c}-0.0927^{* * *} \\
(0.0137)\end{array}$ & $\begin{array}{c}-1.005^{* * *} \\
(0.136)\end{array}$ \\
\hline Some College & $\begin{array}{c}0.000159 \\
(0.0242)\end{array}$ & $\begin{array}{l}0.150^{* * *} \\
(0.0158)\end{array}$ & $\begin{array}{l}0.165^{* * *} \\
(0.0133)\end{array}$ & $\begin{array}{l}0.101^{* * *} \\
(0.0166)\end{array}$ & $\begin{array}{l}-0.151^{* * *} \\
(0.0143)\end{array}$ & $\begin{array}{c}-1.632^{* * *} \\
(0.139)\end{array}$ \\
\hline College & $\begin{array}{c}0.0469 \\
(0.0346)\end{array}$ & $\begin{array}{l}0.151^{* * *} \\
(0.0204)\end{array}$ & $\begin{array}{l}0.182^{* * *} \\
(0.0171)\end{array}$ & $\begin{array}{l}0.106^{* * *} \\
(0.0245)\end{array}$ & $\begin{array}{l}-0.178 * * * \\
(0.0198)\end{array}$ & $\begin{array}{c}-1.763^{* * *} \\
(0.176)\end{array}$ \\
\hline Graduate & $\begin{array}{c}0.0568 \\
(0.0359)\end{array}$ & $\begin{array}{l}0.175^{* * *} \\
(0.0218)\end{array}$ & $\begin{array}{l}0.190^{* * *} \\
(0.0186)\end{array}$ & $\begin{array}{l}0.161^{* * *} \\
(0.0269)\end{array}$ & $\begin{array}{l}-0.221^{* * *} \\
(0.0224)\end{array}$ & $\begin{array}{c}-1.898^{* * *} \\
(0.189)\end{array}$ \\
\hline Controls & YES & YES & YES & YES & YES & YES \\
\hline Regional FE & YES & YES & YES & YES & YES & YES \\
\hline Year FE & YES & YES & YES & YES & YES & YES \\
\hline $\mathrm{R} 2$ between & 0.0740 & 0.0781 & 0.0771 & 0.0309 & 0.0638 & 0.0847 \\
\hline R2 within & 0.0125 & 0.00271 & 0.00208 & 0.00311 & 0.00415 & 0.00305 \\
\hline N Individuals & 20164 & 14269 & 14243 & 19007 & 18966 & 14282 \\
\hline N Observations & 126396 & 36403 & 36227 & 112684 & 111663 & 36537 \\
\hline
\end{tabular}

Notes: Data HILDA, 2001-2013. Sample includes individuals aged 22-65 years old. Robust standard errors clustered at the

individual level reported in parentheses. All models are estimated with a random effects model and include regional and year (wave)

fixed effects. The categories male and married are used as base categories. Statistical significance reported: ${ }^{* *} \mathrm{p}<0.01,{ }^{* *} \mathrm{p}<0.05,{ }^{*}$ $\mathrm{p}<0.1$ 
Table 7: Robustness Check (Additional Controls)

\begin{tabular}{|c|c|c|c|c|c|c|}
\hline & Life Satisfaction & Eudemonic & Hedonic & Pos Affect & Neg Affect & Psych Distress \\
\hline Education & $\begin{array}{c}-0.0249 * * * \\
(0.00443)\end{array}$ & $\begin{array}{c}0.00861^{* * *} \\
(0.00235)\end{array}$ & $\begin{array}{l}0.0124^{* * *} \\
(0.00200)\end{array}$ & $\begin{array}{c}-0.0155^{* * *} \\
(0.00288)\end{array}$ & $\begin{array}{c}-0.00713^{* * *} \\
(0.00234)\end{array}$ & $\begin{array}{l}-0.115^{* * *} \\
(0.0203)\end{array}$ \\
\hline Age & $\begin{array}{c}-0.0763^{* * *} \\
(0.00565)\end{array}$ & $\begin{array}{c}-0.00685^{* *} \\
(0.00322)\end{array}$ & $\begin{array}{c}0.00202 \\
(0.00270)\end{array}$ & $\begin{array}{c}-0.0300^{* * *} \\
(0.00387)\end{array}$ & $\begin{array}{c}0.00396 \\
(0.00310)\end{array}$ & $\begin{array}{c}0.0230 \\
(0.0272)\end{array}$ \\
\hline Age Squared & $\begin{array}{l}0.951^{* * *} \\
(0.0656)\end{array}$ & $\begin{array}{l}0.144^{* * * *} \\
(0.0366)\end{array}$ & $\begin{array}{c}0.0380 \\
(0.0308)\end{array}$ & $\begin{array}{l}0.388^{* * *} \\
(0.0447)\end{array}$ & $\begin{array}{c}-0.154^{* * * *} \\
(0.0355)\end{array}$ & $\begin{array}{c}-0.872^{* * *} \\
(0.310)\end{array}$ \\
\hline Female & $\begin{array}{l}0.00386 \\
(0.0199)\end{array}$ & $\begin{array}{c}-0.122^{* * *} \\
(0.0107)\end{array}$ & $\begin{array}{c}-0.0830^{* * *} \\
(0.00892)\end{array}$ & $\begin{array}{c}-0.165^{* * *} \\
(0.0136)\end{array}$ & $\begin{array}{l}0.197^{* * *} \\
(0.0110)\end{array}$ & $\begin{array}{l}0.997^{* * *} \\
(0.0908)\end{array}$ \\
\hline Single & $\begin{array}{c}-0.386^{* * *} \\
(0.0274)\end{array}$ & $\begin{array}{c}-0.0889^{* * *} \\
(0.0157)\end{array}$ & $\begin{array}{c}-0.0904^{* * *} \\
(0.0127)\end{array}$ & $\begin{array}{c}-0.0998^{* * *} \\
(0.0180)\end{array}$ & $\begin{array}{c}0.0418^{* * *} \\
(0.0149)\end{array}$ & $\begin{array}{c}0.996^{* * * *} \\
(0.130)\end{array}$ \\
\hline Widowed & $\begin{array}{l}-0.261^{* * *} \\
(0.0869)\end{array}$ & $\begin{array}{l}-0.118^{* *} \\
(0.0466)\end{array}$ & $\begin{array}{l}-0.117^{* * * *} \\
(0.0412)\end{array}$ & $\begin{array}{l}-0.0633 \\
(0.0533)\end{array}$ & $\begin{array}{c}0.0614 \\
(0.0422)\end{array}$ & $\begin{array}{c}1.368^{* * * *} \\
(0.436)\end{array}$ \\
\hline Divorced & $\begin{array}{c}-0.600^{* * *} \\
(0.0424)\end{array}$ & $\begin{array}{l}-0.152^{* * * *} \\
(0.0230)\end{array}$ & $\begin{array}{c}-0.129^{* * *} \\
(0.0180)\end{array}$ & $\begin{array}{l}-0.112^{* * * *} \\
(0.0263)\end{array}$ & $\begin{array}{l}0.117^{* * *} \\
(0.0208)\end{array}$ & $\begin{array}{c}1.464^{* * *} \\
(0.189)\end{array}$ \\
\hline Separated & $\begin{array}{c}-0.847^{* * *} \\
(0.0576)\end{array}$ & $\begin{array}{c}-0.245^{* * *} \\
(0.0333)\end{array}$ & $\begin{array}{l}-0.176^{* * *} \\
(0.0268)\end{array}$ & $\begin{array}{l}-0.232^{* * * *} \\
(0.0346)\end{array}$ & $\begin{array}{l}0.246^{* * *} \\
(0.0290)\end{array}$ & $\begin{array}{c}2.184^{* * * *} \\
(0.277)\end{array}$ \\
\hline Employed & $\begin{array}{c}0.0362 \\
(0.0466)\end{array}$ & $\begin{array}{l}0.0564^{* *} \\
(0.0234)\end{array}$ & $\begin{array}{c}0.0112 \\
(0.0177)\end{array}$ & $\begin{array}{c}0.0131 \\
(0.0281)\end{array}$ & $\begin{array}{l}-0.0116 \\
(0.0230)\end{array}$ & $\begin{array}{c}-0.340^{*} \\
(0.186)\end{array}$ \\
\hline Log Labor Income & $\begin{array}{l}-0.00330 \\
(0.00469)\end{array}$ & $\begin{array}{l}0.00518^{* *} \\
(0.00236)\end{array}$ & $\begin{array}{c}0.00637^{* * * *} \\
(0.00178)\end{array}$ & $\begin{array}{l}0.000796 \\
(0.00283)\end{array}$ & $\begin{array}{c}-0.00610^{* * *} \\
(0.00234)\end{array}$ & $\begin{array}{c}-0.0583^{* * *} \\
(0.0188)\end{array}$ \\
\hline Fair Health & $\begin{array}{l}0.940^{* * * *} \\
(0.0852)\end{array}$ & $\begin{array}{l}0.492^{* * *} \\
(0.0487)\end{array}$ & $\begin{array}{l}0.356^{* * *} \\
(0.0417)\end{array}$ & $\begin{array}{l}0.403^{* * *} \\
(0.0427)\end{array}$ & $\begin{array}{l}-0.531^{* * *} \\
(0.0391)\end{array}$ & $\begin{array}{c}-3.998^{* * *} \\
(0.418)\end{array}$ \\
\hline Good Health & $\begin{array}{l}1.424^{* * *} \\
(0.0834)\end{array}$ & $\begin{array}{l}0.869^{* * *} \\
(0.0470)\end{array}$ & $\begin{array}{l}0.640^{* * * *} \\
(0.0407)\end{array}$ & $\begin{array}{l}0.878 * * * \\
(0.0421)\end{array}$ & $\begin{array}{l}-0.977^{* * *} \\
(0.0383)\end{array}$ & $\begin{array}{c}-7.197^{* * *} \\
(0.407)\end{array}$ \\
\hline Very Good Health & $\begin{array}{l}1.803^{* * *} \\
(0.0837)\end{array}$ & $\begin{array}{l}1.019^{* * *} \\
(0.0470)\end{array}$ & $\begin{array}{l}0.789^{* * *} \\
(0.0407)\end{array}$ & $\begin{array}{l}1.213^{* * *} \\
(0.0425)\end{array}$ & $\begin{array}{l}-1.207^{* * *} \\
(0.0386)\end{array}$ & $\begin{array}{c}-8.753^{* * *} \\
(0.407)\end{array}$ \\
\hline Excellent Health & $\begin{array}{l}2.165^{* * *} \\
(0.0857)\end{array}$ & $\begin{array}{l}1.066^{* * *} \\
(0.0478)\end{array}$ & $\begin{array}{l}0.865^{* * *} \\
(0.0415)\end{array}$ & $\begin{array}{l}1.428^{* * *} \\
(0.0448)\end{array}$ & $\begin{array}{l}-1.352^{* * *} \\
(0.0403)\end{array}$ & $\begin{array}{c}-9.435^{* * *} \\
(0.414)\end{array}$ \\
\hline Exercise (rarely) & $\begin{array}{l}0.0821^{* *} \\
(0.0367)\end{array}$ & $\begin{array}{l}0.114^{* * *} \\
(0.0218)\end{array}$ & $\begin{array}{c}0.0842^{* * *} \\
(0.0175)\end{array}$ & $\begin{array}{l}0.0988^{* * *} \\
(0.0239)\end{array}$ & $\begin{array}{c}-0.102^{* * *} \\
(0.0199)\end{array}$ & $\begin{array}{c}-0.920^{* * *} \\
(0.180)\end{array}$ \\
\hline Every week & $\begin{array}{l}0.137^{* * *} \\
(0.0336)\end{array}$ & $\begin{array}{l}0.152^{* * *} \\
(0.0199)\end{array}$ & $\begin{array}{l}0.105^{* * *} \\
(0.0163)\end{array}$ & $\begin{array}{l}0.169^{* * *} \\
(0.0221)\end{array}$ & $\begin{array}{c}-0.183^{* * *} \\
(0.0185)\end{array}$ & $\begin{array}{c}-1.168^{* * * *} \\
(0.167)\end{array}$ \\
\hline Agreeableness & $\begin{array}{l}0.125^{* * *} \\
(0.0121)\end{array}$ & $\begin{array}{c}-0.000225 \\
(0.00695)\end{array}$ & $\begin{array}{c}0.00419 \\
(0.00577)\end{array}$ & $\begin{array}{l}0.104^{* * *} \\
(0.00792)\end{array}$ & $\begin{array}{c}0.00111 \\
(0.00665)\end{array}$ & $\begin{array}{l}-0.0172 \\
(0.0591)\end{array}$ \\
\hline Conscientiousness & $\begin{array}{l}0.0581^{* * *} \\
(0.00987)\end{array}$ & $\begin{array}{l}0.0651^{* * *} \\
(0.00556)\end{array}$ & $\begin{array}{l}0.0399^{* * * *} \\
(0.00450)\end{array}$ & $\begin{array}{l}0.0388^{* * *} \\
(0.00675)\end{array}$ & $\begin{array}{c}-0.0469^{* * * *} \\
(0.00533)\end{array}$ & $\begin{array}{c}-0.490^{* * *} \\
(0.0458)\end{array}$ \\
\hline Emotional Stability & $\begin{array}{l}0.167^{* * *} \\
(0.0100)\end{array}$ & $\begin{array}{c}0.179^{* * *} \\
(0.00586)\end{array}$ & $\begin{array}{c}0.172^{* * *} \\
(0.00467)\end{array}$ & $\begin{array}{c}0.223^{* * *} \\
(0.00668)\end{array}$ & $\begin{array}{l}-0.209^{* * *} \\
(0.00546)\end{array}$ & $\begin{array}{c}-1.790^{* * *} \\
(0.0479)\end{array}$ \\
\hline Extroversion & $\begin{array}{c}0.105^{* * *} \\
(0.00878)\end{array}$ & $\begin{array}{l}0.0713^{* * *} \\
(0.00487)\end{array}$ & $\begin{array}{l}0.0492^{* * *} \\
(0.00390)\end{array}$ & $\begin{array}{c}0.112^{* * *} \\
(0.00604)\end{array}$ & $\begin{array}{c}-0.0805^{* * * *} \\
(0.00486)\end{array}$ & $\begin{array}{l}-0.598^{* * *} \\
(0.0400)\end{array}$ \\
\hline
\end{tabular}




\begin{tabular}{|c|c|c|c|c|c|c|}
\hline Openness & $\begin{array}{c}-0.0360^{* * *} \\
(0.00999)\end{array}$ & $\begin{array}{c}-0.0279^{* * *} \\
(0.00542)\end{array}$ & $\begin{array}{c}-0.0216^{* * * *} \\
(0.00441)\end{array}$ & $\begin{array}{l}-0.0146^{* *} \\
(0.00665)\end{array}$ & $\begin{array}{l}0.0213^{* * *} \\
(0.00545)\end{array}$ & $\begin{array}{l}0.244^{* * *} \\
(0.0455)\end{array}$ \\
\hline Regional FE & YES & YES & YES & YES & YES & YES \\
\hline Year FE & YES & YES & YES & YES & YES & YES \\
\hline R2 between & 0.259 & 0.359 & 0.371 & 0.333 & 0.386 & 0.401 \\
\hline R2 within & 0.0823 & 0.120 & 0.120 & 0.127 & 0.146 & 0.143 \\
\hline $\mathrm{N}$ Individuals & 13964 & 12163 & 12135 & 13914 & 13845 & 12194 \\
\hline N Observations & 25794 & 17869 & 17785 & 25672 & 25454 & 17933 \\
\hline
\end{tabular}

